Journal of Radioanalytical and Nuclear Chemistry, Articles, Vol. 140, No. 2 (1990) 301-313

\title{
CESIUM SORPTION ON MYLONITE
}

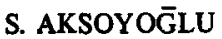

Poul Scherrer Institute, CH-5232, Villigen PSI (Switzerland)

(Received October 12, 1989)

As part of the laboratory support program for the field migration experiment at the Grimsel Test Site (GTS) in the Swiss Alps, the sorption behaviour of cesium on Crimsel mylonite was studied. Batch sorption experiments were carried out in $\mathrm{N}_{2}$ atmosphere $\left(<3 \mathrm{ppm} \mathrm{O}_{2}\right)$. The adsorption isotherms were reversible and non-linear for cesium concentrations of between $3.2 \cdot 10^{-8}$ and $5.0 \cdot 10^{-4} \mathrm{M}$. Two different sites appear to be involved in sorption depending on whether Cs loading was high $\left(10^{-6}-10^{-3} \mathrm{meq} / \mathrm{g}\right)$ or low $\left(10^{-7}-10^{-6} \mathrm{meq} / \mathrm{g}\right)$. At low Cs loadings adsorption was considered to occur mainly at the crystal edges of mica particles. Selectivity coefficients for exchange between cesium and potassium were calculated for different Cs loadings. It was suggested that by varying the potassium concentration of the solution and by making some assumptions, a $K_{d}$ value for cesium at the migration site could be estimated. Data were fitted to both Freundlich and Dubinin-Radushkevich isotherms. The empirical Freundlich parameters enabled a site distribution function to be calculated and a mean energy of sorption of about $12 \mathrm{~kJ} / \mathrm{mol}$ was found using Dubinin-Radushkevich isotherms approach.

\section{Introduction}

An extensive single fissure radionuclide migration experiment is in progress in NAGRA's Grimsel Test Site in the Swiss Alps.' This experiment requires supporting laboratory data in order to understand the retardation mechanisms involved and for transport modelling studies. Previous studies investigated the rock-water inieraction and sorption of both conservative (I, $\mathrm{Br}$ ) and ideally sorbing tracers $(\mathrm{Na}, \mathrm{Sr})$ on mylonite. ${ }^{2}{ }^{3}$ Mylonite which is the typical fracture infill material found at GTS is composed mainly of quartz, mica and feldspar. ${ }^{4}$ These sorption works have now been extended to another tracer-Cs.

Cesium is of concern in waste repository safety assessments owing to the large inventories, long half-lives of its isotopes $\left(10^{6}\right.$ years for ${ }^{135} \mathrm{Cs}$ and 30 years for $137 \mathrm{Cs}$ ) and its high solubility. In addition, its chemistry is simple, hence it is particularly suitable for an investigation of sorption processes. Complex formation of cesium in the hydrosphere can be neglected because $\mathrm{Cs}^{+}$ions do not form stable complexes with the anions usually found in groundwater while changes in $\mathrm{pH}$ and Eh do 
not influence its speciation. For these reasons, the sorption behaviour of Cs has been studied extensively. ${ }^{5-12}$

Cesium usually adsorbs predominantly by ion-exchange and the extent of uptake depends strongly on the competing cations. ${ }^{7,9,12,13}$ For example, the sorption of cesium on micas is governed by the size and hydration of, rather than the valence, of the competing cation. 5 The potassium ion can have a particularly strong influence on cesium adsorption because Cs can replace potassium at the edges of the mica particles and so may be incorporated into the crystal structure. ${ }^{5}$ Adsorption of $\mathrm{Cs}$ on quartz and felspar is negligible in comparison with that on mica ${ }^{14}$

To avoid changes in ionic composition during the sorption experiments, these experiments were always performed using water that had been equilibrated with mylonite. During the equilibration period a considerable amount of $\mathrm{K}^{+}$came into the solution from the mylonite due to exchange processes, so the potassium concentration of the equilibrated water was much higher than that of the in-situ Grimsel water. Partly for this reason, the $K_{d}$ of $C s$ on mylonite found in the laboratory can differ from that in the field and the extrapolation of the laboratory value to in-situ conditions required an investigation of the competition between cesium and potassium for sorption sites.

\section{Materials and methods}

Sorption experiments were carried out on mylonite sampled from a fault zone near the site of the in-situ experiments. ${ }^{4}$ After sampling, the rock was crushed and sieved through a $63 \mu \mathrm{m}$ sieve in the glove-box in a $\mathrm{N}_{2}$ atmosphere containing less than $3 \mathrm{ppm}$ of both $\mathrm{O}_{2}$ and $\mathrm{CO}_{2}$.

All laboratory experiments were carried out using the natural Grimsel groundwater (NGW), which flows through the mylonitic fracture zone. NGW is a groundwater of low ionic strength $\left(\sim 10^{-3} \mathrm{M}\right)$, and high $\mathrm{pH}$, with $\mathrm{Na}^{+}$and $\mathrm{Ca}^{2+}$ as major cations and $\mathrm{Cl}^{-}, \mathrm{SO}_{4}^{2-}, \mathrm{F}^{-}$and $\mathrm{CO}_{3}^{2-} / \mathrm{HCO}_{3}^{-}$as major anions.

Before use, the NGW was equilibrated with mylonite. This equilibration period was necessary to avoid changes in the solution composition as a result of ion exchange processes, during the sorption experiments The compositions of the natural and equilibrated water are given in Table 1 . Except for potassium which has increased, the composition of the two waters are very similar.

The preliminary rock/water equilibration, with a rock/water ratio of $1 / 10$, was carried out by holding mylonite samples in dialysis bags $(2.4 \mathrm{~nm}$ pore size) in a glove box. Dialysis bags were used to avoid the problems associated with phase separation by filtration or centrifugation. The equilibrated water had a potassium concentration about 20 times higher than in NGW, which could cause discrepancies between the results from laboratory and field sorption experiments. 
All the batch sorption tests were carried out in dialysis bags, in duplicates, at a rock to water ratio of $1 / 10$ and with gentle agitation on an end-over end shaker, in the glove box. In parallel, some blank samples were also used to check for any loss on the containers or on the dialysis bags. Most sorption experiments were carried out

Table 1

Compositions of natural and equilibrated Grimsel groundwater

\begin{tabular}{|c|c|c|}
\hline \multirow{2}{*}{ Ions } & \multicolumn{2}{|c|}{ Concentration, $\mathbf{M}$} \\
\hline & Natural & Equilibrated \\
\hline $\mathbf{K}^{+}$ & $3.84 \cdot 10^{-6}$ & $7.7 \cdot 10^{-5}$ \\
\hline $\mathrm{Na}^{+}$ & $6.92 \cdot 10^{-4}$ & $6.7 \cdot 10^{-4}$ \\
\hline $\mathrm{Ca}^{9+}$ & $1.27 \cdot 10^{-4}$ & $1.1 \cdot 10^{-4}$ \\
\hline $\mathrm{Mg}^{2+}$ & $1.2 \cdot 10^{-6}$ & $9.2 \cdot 10^{-6}$ \\
\hline $\mathrm{Sr}^{2+}$ & $1.84 \cdot 10^{-6}$ & $8.2 \cdot 10^{-7}$ \\
\hline $\mathrm{Cs}^{+}$ & $4.5 \cdot 10^{-9}$ & $2.0 \cdot 10^{-10}$ \\
\hline $\mathbf{F}^{-}$ & $3.3 \cdot 10^{-4}$ & $3.4 \cdot 10^{-4}$ \\
\hline $\mathrm{a}^{-}$ & $1.55 \cdot 10^{-4}$ & $1.6 \cdot 10^{-4}$ \\
\hline $\mathrm{SO}_{4}^{2-}$ & $5.7 \cdot 10^{-5}$ & $7.4 \cdot 10^{-5}$ \\
\hline Alkalinity & $4.2 \cdot 10^{-4}$ & $4.1 \cdot 10^{-4}$ \\
\hline pH & 9.6 & 9.5 \\
\hline Conductivity $(\mu \mathrm{S} / \mathrm{cm})$ & 103.0 & - \\
\hline
\end{tabular}

using the equilibrated groundwater. However, in order to investigate the competition of $\mathbf{K}$ and $\mathrm{Cs}$ for sorption sites, one series of experiments was carried out using equilibrated NGW to which sufficient $\mathrm{K}^{+}$had been added to increase the concentration to $6.4 \cdot 10^{-4} \mathrm{M}$. Total cesium concentrations ranged between $3.2 \cdot 10^{-8}$ and $5.0 \cdot 10^{-4} \mathrm{M}$. Cs solutions were prepared with inactive $\mathrm{CsCl}$ labeled with ${ }^{137} \mathrm{Cs}$ tracer. The kinetics of cesium sorption was followed to determine the time required to reach the steady state. Desorption experiments were carried out by replacing half of the spiked solution with the equilibrated water. The samples were shaken as before and each sample was sampled twice after 20 and 40 days.

The cations and anions in the solutions were measured by atomic absorption spectrometry and ion chromatography, respectively. The trace cesium concentrations were determined by ICP.MS. The gamma activity of ${ }^{137} \mathrm{Cs}(661 \mathrm{keV})$ was measured by means of an intrinsic germanium detector connected to a multichannel analyzer. The exchangeable cations were determined by the silver-thiourea (AgTU) method. ${ }^{5}$ This method involves saturation of the rock with AgTU complex with the simultaneous removal of all the exchangeable cations. The cation exchange capacity was measured by the sodium acetate method in which the solid is saturated with sodium at $\mathrm{pH} 8.2$ and then extracted with magnesium nitrate ${ }^{16}$ 


\section{S. AKSOYOḠLU: CESIUM SORPTION ON MYLONITE}

\section{Results and discussion}

Data obtained from blanks showed that the loss of cesium on the containers used was negligible $(<1 \%)$, whereas dialysis bags sorb between 0 and $5 \%$, depending on the cesium concentration in the solution. However, this loss is not significant when the high sorption of cesium on mylonite is taken into account Plots of the sorption and desorption coefficients $\left(R_{S}\right.$ and $R_{D}$ respectively) against $C s$ loading on mylonite for the two series with different $\mathrm{K}$ contents are shown in Fig. 1. The sorption values

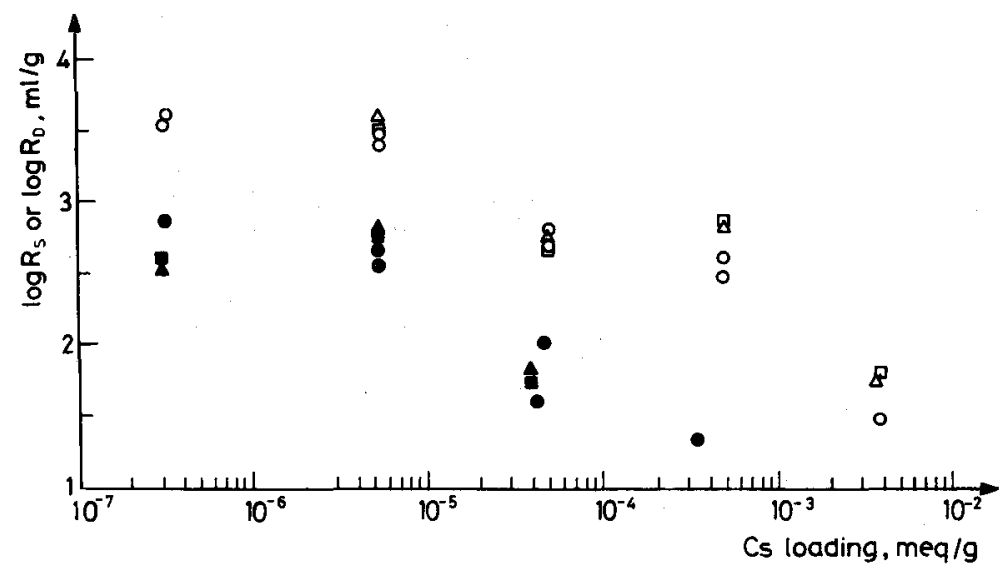

Fig. 1. Change of $R_{S}$ and $R_{D}$ with Cs loading; o sorption, $\left[K^{+}\right]=7.7 \cdot 10^{-5} \mathrm{M}, \Delta 1$ st desorption, $\left[\mathrm{K}^{+}\right]=7.7 \cdot 10^{-5} \mathrm{M}$, 口 2 nd desorption, $\left[\mathrm{K}^{+}\right]=7.7 \cdot 10^{-5} \mathrm{M}, \bullet$ sorption, $\left[\mathrm{K}^{+}\right]=6.4 \cdot 10^{-4} \mathrm{M}$, - 1st desorption, $\left[\mathrm{K}^{+}\right]=6.4 \cdot 10^{-4} \mathrm{M}, \triangle 2$ 2nd desorption, $\left[\mathrm{K}^{+}\right]=6.4 \cdot 10^{-4} \mathrm{M}$

were measured after 30 days, whereas, 1 st and 2 nd desorption values were measured after 20 and 40 days respectively. Generally, the values of duplicates for sorption are close to each other and there is no significant difference between 1st and 2nd desorption data. The $R_{S}$ values are in agreement with the results for similar types of rocks and water systems in the same concentration range. ${ }^{9}$ The changes in the coefficients with the cesium loading in both cases (high and low $\mathrm{K}$ levels) are similar. Both sorption and desorption coefficients increase as the Cs loading decreases. At the lowest Cs loading, the solution concentrations are at nearly the same level as the stable Cs in NGW. Between $3 \cdot 10^{-7}$ and $5 \cdot 10^{-6} \mathrm{meq} / \mathrm{g}$ Cs loading, $\mathrm{R}_{\mathrm{S}}$ changes only slightly, whereas at loadings betwen $5 \cdot 10^{-6}$ and $3 \cdot 10^{-3} \mathrm{meq} / \mathrm{g}$, it decreases significantly: this suggests that energetically less favourable sites become involved with increasing Cs concentration.

TITLYANOVA ${ }^{6}$ reports that micas display two forms of cesium sorption; incorporation in the structure of the minerals at low concentrations and ion exchange at higher 


\section{S. AKSOYOGLU: CESIUM SORPTION ON MYLONITE}

concentrations. In view of this, slow desorption in the low concentration region is expected. However, all our desorption coefficients agree well with sorption coefficients, indicating that at low cesium loadings irreversible fixation of cesium in the structure has not occurred within the experimental timescale used. However, trace amounts of cesium are known to be preferentially adsorbed at certain specific sites located at the crystal edges. 5,17 These sites are known as frayed edge sites, FES or edge interlattice sites; they have a high selectivity for $\mathrm{Cs}$ and $\mathrm{K}$ and exchange at these sites is very rapid. ${ }^{17}$ The high sorption of cesium in the low concentration range can be attributed to such sites as discussed in the following.

\section{Selectivity coefficients}

The stoichiometric selectivity coefficient, $\mathbf{K}_{c}$, for an exchange between cesium and potassium can be written as:

$$
\mathrm{K}_{\mathrm{c}}(\mathrm{Cs}-\mathrm{K})=\frac{\mathrm{N}_{\mathrm{Cs}} \cdot\left[\mathrm{K}^{+}\right]}{\mathrm{N}_{\mathrm{K}} \cdot\left[\mathrm{Cs}^{+}\right]}
$$

where $\mathrm{N}$ denotes the fractional occupancies of the cations, and $\left[\mathrm{K}^{+}\right]$and $\left[\mathrm{Cs}^{+}\right]$are the molar concentrations in the solutions. ${ }^{18}$

$\mathrm{K}_{\mathrm{c}}$ values were calculated for different $\mathrm{Cs}$ loadings, using the data obtained from sorption and exchangeable cation experiments. The change of $\mathbf{K}_{\mathbf{c}}$ with Cs loading is shown in Fig. 2 for two solutions with different $\mathrm{K}$ concentrations. The selectivity

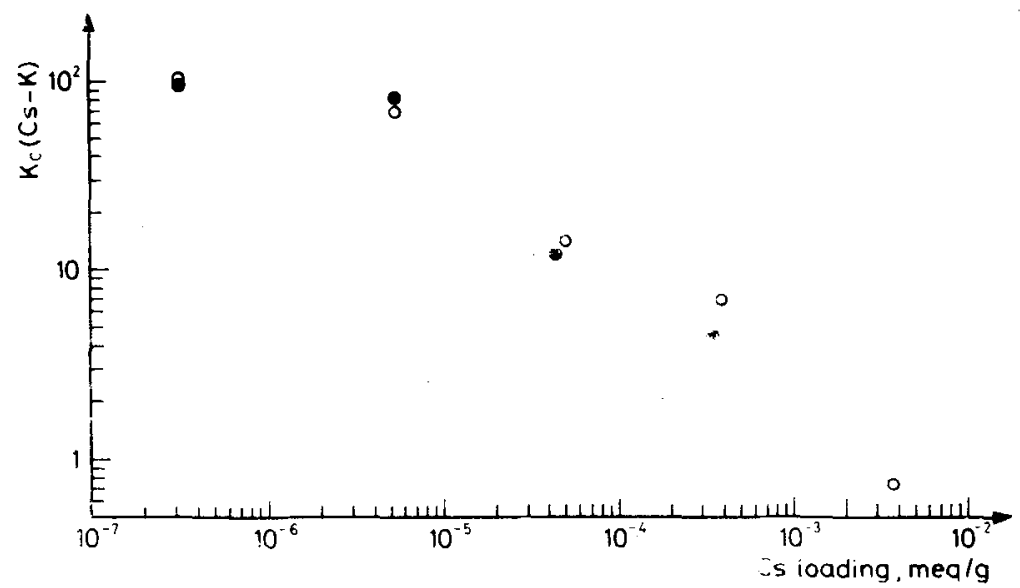

Fig. 2. Change in selectivity coefficient with $\mathrm{Cs}$ loading; $\circ\left[\mathrm{K}^{+}\right]=7.7 \cdot 10^{-5} \mathrm{M}, \bullet\left[\mathrm{K}^{+}\right]=6.4 \cdot 10^{-4} \mathrm{M}$ 


\section{S. AKSOYOGLU: CESIUM SORPTION ON MYLONITE}

coefficient decreases with increasing Cs loading, again suggesting the presence of different types of sorption sites (cf. Fig. 1). Selectivity coefficients for both cases are the same at the lowest cesium loading $\left(K_{c} \sim 100\right)$. This means that as Cs concentration (and $\mathrm{Cs}$ loading) goes to zero, $\mathrm{K}_{\mathrm{c}}(\mathrm{Cs}-\mathrm{K})$ tends to remain constant despite varying $K$ concentrations and varying $K_{d}$ for Cs. This behaviour is an indication of an ion exchange process between $\mathrm{Cs}$ and $\mathrm{K} .^{9}$

The selectivity coefficient $\mathbf{K}_{\mathbf{c}}$ for FES sites is defined as:

$$
\mathrm{K}_{\mathrm{c}}(\mathrm{Cs}-\mathrm{K})=\frac{\mathrm{z}_{\mathrm{Cs}} \cdot\left[\mathrm{K}^{+}\right]}{\mathrm{z}_{\mathrm{K}} \cdot\left[\mathrm{Cs}^{+}\right]}
$$

where $z$ denotes the fraction of FES occupied by Cs or K. Since these sites are mainly occupied by potassium, i.e. $\left(z_{K} \sim 1\right)^{12}$ the equation becomes

$$
\mathrm{K}_{\mathrm{c}}\left(\mathrm{z}_{\mathrm{Cs}} \rightarrow 0\right)=\frac{\left(\mathrm{m}_{\mathrm{Cs}} /[\mathrm{FES}]\right) \cdot\left[\mathrm{K}^{+}\right]}{1 \cdot\left[\mathrm{Cs}^{+}\right]}
$$

where $m_{C s}$ is the amount of cesium on the edge sites (meq/g) and [FES] is the number of frayed edge sites (meq/g). In this equation, $\mathrm{m}_{\mathrm{Cs}} /\left[\mathrm{Cs}^{+}\right]$corresponds to the $\mathrm{K}_{\mathrm{d}}$ of cesium at the lowest $\mathrm{Cs}$ loading, assuming that $\mathrm{Cs}$ is sorbed predominantly on such sites: Therefore, the equation rearranges to:

$$
\mathrm{K}_{\mathrm{c}}\left(\mathrm{z}_{\mathrm{Cs}} \rightarrow 0\right)=\frac{\mathrm{K}_{\mathrm{d}}(\mathrm{Cs}) \cdot\left[\mathrm{K}^{+}\right]}{[\mathrm{FES}]}
$$

Since at the lowest $\mathrm{Cs}$ loading (obtained using ${ }^{13}{ }^{7} \mathrm{Cs}$ tracer alone) $\mathrm{K}_{\mathrm{c}}$ and FES are constant, the product of $\mathrm{K}_{\mathrm{d}}$ and $\left[\mathrm{K}^{+}\right]$should remain constant as potassium concentration varies. In fact, it was found to be $0.31 \mathrm{meq} / \mathrm{g}$ for both cases. This finding supports the above reasoning. Using this value for $K_{d} \cdot\left[K^{+}\right]$permits estimation of the $K_{d}$ for cesium (at Cs loadings $<10^{-6} \mathrm{meq} / \mathrm{g}$ ), for other potassium levels in the water. By assuming that the rock at the field site behaves in a similar manner to the crushed rock used in the laboratory, the in-situ $K_{d}$ for Cs can be estimated using potassium concentration in groundwater. Competition of other ions in the solution (such as $\mathrm{Na}, \mathrm{Ca}$ and $\mathrm{Sr}$ ) with cesium for these specific sites at the low cesium concentration was not considered in this approach, because the smaller hydrated ions (such as $\mathrm{K}$ and $\mathrm{Cs}$ ) are considered to be preferred by such sites more than the larger hydrated ions. ${ }^{17,19,20}$ 


\section{Sorption isotherms}

Data obtained from sorption experiments with cesium in the concentration range of $5.3 \cdot 10^{-7}-5.0 \cdot 10^{-4} \mathrm{M}$ were fitted to Freundlich isotherm. ${ }^{21}$ The data for the smallest initial cesium concentration of $3.2 \cdot 10^{-8} \mathrm{M}$ was not used for Freundlich isotherm, since it was close to the natural $\mathrm{Cs}$ concentration level in groundwater.

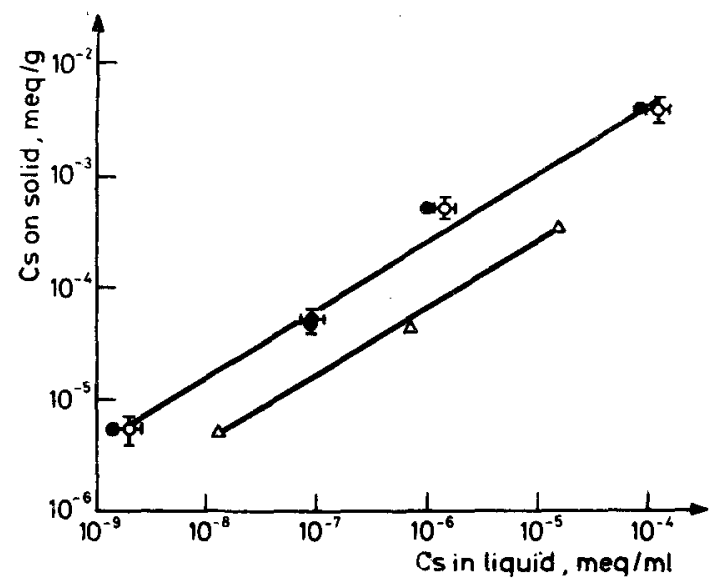

Fig. 3. Freundlich isotherms of $\mathrm{Cs}$ sorption on mylonite; $\mathrm{O}$ sorption, $\left[\mathrm{K}^{+}\right]=7.7 \cdot 10^{-5} \mathrm{M}$, $\bullet$ desorption, $\left[\mathrm{K}^{+}\right]=7.7 \cdot 10^{-5} \mathrm{M}, \Delta$ sorption, $\left[\mathrm{K}^{+}\right]=6.4 \cdot 10^{-4} \mathrm{M}$

Although the Freundlich isotherm does not take the solid's finite capacity for adsorption at high concentrations into account; it often describes adsorption of trace amounts of adsorbing species satisfactorily..$^{2-25}$ The linearized Freundlich equation is:

$$
\log \mathrm{X}=\log \mathrm{A}+\mathrm{N} \log \mathrm{C}
$$

where X - amount of solute adsorbed per unit weight of solid (meq/g),

C - equilibrium solute solution concentration $(\mathrm{meq} / \mathrm{ml})$,

A, $\mathbf{N}$ - constants.

The Freundlich isotherm obtained is shown in Fig. 3. Linear regression gave a slope of less than 1, indicating a concentration dependent sorption of cesium in the concentration range used. The Freundlich parameters for systems with different potassium concentrations are given in Table 2. The Freundlich exponents $(\mathrm{N})$ are comparable with those found in other studies $(0.52-0.75)$ on granitic rocks with the same cesium concentration range. $23,24,26-28$ Although the Freundlich isotherm is generally regarded as empirical, there have been some attempts to derive some information about 


\section{S. AKSOYOGLU: CESIUM SORPTION ON MYLONITE}

the surface heterogeneity from the empirical Freundlich constants. ${ }^{29,30}$ For adsorption of an ion $A$, which participates in an exchange reaction with an ion $B$, it is assumed that the exchanger surface is heterogeneous. The assumption that each class of exchange sites adsorbs individually accordingly to the Langmuir isotherm, enables the

Table 2

Freundlich parameters for cesium sorption on mylonite

\begin{tabular}{lcccc}
\hline & $\mathrm{K}^{+}(\mathrm{M})$ & $\mathrm{A}$ & $\mathrm{N}$ & $\mathrm{r}$ \\
\hline Sorption & $7.7 \cdot 10^{-5}$ & 1.02 & 0.60 & 0.9938 \\
Desorption & $7.7 \cdot 10^{-5}$ & 1.78 & 0.62 & 0.9877 \\
Sorption & $6.4 \cdot 10^{-4}$ & 0.71 & 0.59 & 0.9970 \\
\hline
\end{tabular}

empirical Freundlich parameters to be used to characterize the sorption site distribution function mathematically. This provides information about surface heterogeneity in the exchanger. The site distribution function is given by SPOSITO as: $:^{31}$

$$
m(q)=m_{m a x} \cdot \frac{2 \cos (\pi N) \exp \left[N\left(q_{m}-q\right)\right]+2 \exp \left[N\left(q_{m}-q\right)\right]}{1+2 \cos (\pi N) \exp \left[N\left(q_{m}-q\right)\right]+\exp \left[2 N\left(q_{m}-q\right)\right]}
$$

where $m(q)$ - number of sites of class $q$,

$m_{m a x}$ - the value of $m(q)$ at its maximum,

$q_{m} \quad$ value of $q$ when $m(q)=m_{m a x}$,

N - Freundlich exponent;

$\mathrm{q}$ represents the class of adsorption sites and is defined as:

$$
q \equiv \ln \left(K_{A} / K_{B}\right)
$$

where $K_{A}$ and $K_{B}$ are the affinity parameters for the species $A$ and $B .^{31}$ $\mathrm{m}_{\mathrm{m} \text { ax }}$ can be calculated from:

$$
m_{\max }=\frac{M}{2 \pi} \tan (\pi N / 2)
$$

where $M$ is the total number of adsorption sites. $q_{m}$ can be calculated from:

$$
\mathrm{q}_{\mathrm{m}}=(1 / \mathrm{N}) \ln \alpha
$$


where $\alpha$ is a parameter which can be calculated from:

$$
\alpha=A c_{B}{ }^{N} / M
$$

$A$ and $N$ are the Freundlich constants and $c_{B}$ is the average value of concentration of the species $B$. Using $q_{m}$ and $m_{m a x}$ for exchange between cesium and potassium $\left(\mathrm{A}=\mathrm{Cs}^{+}, \mathrm{B}=\mathrm{K}^{+}\right)$, the site distribution has been calculated. The parameters used in this equation are the followings:

$$
\begin{aligned}
& A=1.02 \\
& N=0.60 \\
& C_{B}=7.7 \cdot 10^{-5} \mathrm{meq} / \mathrm{ml} \\
& M=0.019 \mathrm{meq} / \mathrm{g} \\
& \alpha=0.178 \\
& \mathrm{q}_{\mathrm{m}}=-2.87
\end{aligned}
$$

The values of $m(q)$ were calculated for $q$ values between -20 and +20 (arbitrarily chosen at both sites of $q_{m}$ ). As is seen in Fig. 4 , the sites are distributed over a

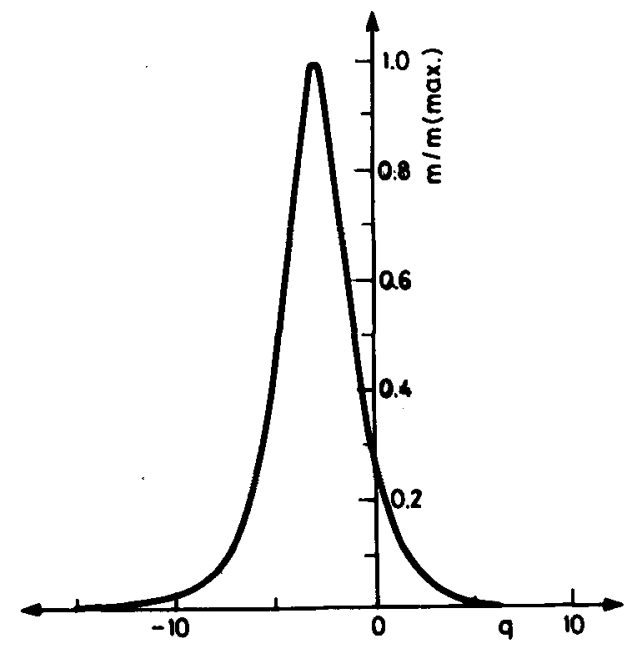

Fig 4. Site distribution on mylonite

number of classes, suggesting that the exchange is not restricted to one specific class of sites. The mainly negative value of $\mathrm{q}_{m}$ indicates that most of the sorption sites have a higher affinity for potassium than for cesium. However, there are also some sites having a higher affinity for cesium than potassium. 


\section{S. AKSOYOG̈LU: CESIUM SORPTION ON MYLONITE}

As an alternative to Freundlich isotherm, the data were fitted to the DubininRadushkevich (D-R) equation: ${ }^{32}$

$$
X=X_{m} \exp \left(-K \epsilon^{2}\right)
$$

where X - amount of solute adsorbed per unit weight of solid (mol/g),

$\mathrm{X}_{\mathrm{m}}$ - sorption capacity of adsorbent per unit weight $(\mathrm{mol} / \mathrm{g})$,

$\epsilon \quad-$ Polanyi potential $=\mathrm{RT} \ln (1+1 / \mathrm{C})$,

$\mathrm{C}$ - equilibrium solute solution concentration $(\mathrm{mol} / \mathrm{l})$,

$\mathrm{R}$ - gas constant ( $\mathrm{kJ} / \mathrm{deg}$. $\mathrm{mol})$,

$\mathrm{T}$ - temperature $(\mathrm{K})$,

$\mathrm{K}$ - constant related to the sorption energy $\left(\mathrm{mol}^{2} / \mathrm{kJ}^{2}\right)$.

The linearized $D-R$ equation is:

$$
\ln X=\ln X_{m}-K \epsilon^{2}
$$

By making certain assumptions ${ }^{\mathbf{3} 3}$ (i.e. assuming a very small subregion of sorption surface to be uniform in structure and energetically homogeneous and by applying Langmuir's isotherm as local isotherm), the mean energy of sorption, E, can be calculated, from D-R parameters. The mean energy of sorption is the free energy change when one mole of ion is transferred to the surface of the solid from the infinity in the solution and it is calculated from: $:^{34,35}$

$$
E=(-2 K)^{-1 / 2}
$$

The magnitude of $\mathrm{E}$ can indicate the type of sorption occurring. The parameters obtained from the fitting of sorption data to $D-R$ isotherm are shown in Table 3 .

The mean energy of sorption was found to be about $12 \mathrm{~kJ} / \mathrm{mol}$, which is in the energy range for ion exchange reactions, $8-16 \mathrm{~kJ} / \mathrm{mol} .^{36}$ This value is also in a good agreement with literature values calculated in the same way. ${ }^{33,37}$

Table 3

D-R parameters for cesium sorption on mylonite

\begin{tabular}{lccccc}
\hline & $\mathrm{K}^{+}(\mathrm{M})$ & $\mathrm{X}_{\mathrm{m}}(\mathrm{mol} / \mathrm{g})$ & $\mathrm{K}\left(\mathrm{mol}^{2} / \mathrm{kJ}^{2}\right)$ & $\mathrm{E}(\mathrm{kJ} / \mathrm{mol})$ & $\mathrm{r}$ \\
\hline Sorption & $7.7 \cdot 10^{-5}$ & $1.77 \cdot 10^{-5}$ & $-3.49 \cdot 10^{-3}$ & 11.97 & 0.9945 \\
Desorption & $7.7 \cdot 10^{-5}$ & $2.17 \cdot 10^{-5}$ & $3.40 \cdot 10^{-3}$ & 12.13 & 0.9862 \\
Sorption & $6.4 \cdot 10^{-4}$ & $3.27 \cdot 10^{-6}$ & $-3.58 \cdot 10^{-3}$ & 11.82 & 0.9904 \\
\hline
\end{tabular}


The maximum sorption capacity found using the $D-R$ equation, for the solution with the lower potassium concentration, is $1.8 \mathrm{meq} / 100 \mathrm{~g}$, which should represent the maximum sorption capacity of mylonite under our conditions. This corresponds to about $95 \%$ of its total cation exchange capacity $(1.9 \mathrm{meq} / 100 \mathrm{~g})$. The high correlation between sorption capacity and cation exchange capacity indicates that, as expected, Cs is present predominantly as an uncomplexed cation and sorbs by ion exchange. However, in the solutions with a tenfold higher potassium concentration, the maximum sorption capacity for $\mathrm{Cs}$ decreases to $0.33 \mathrm{meq} \mathrm{Cs} / 100 \mathrm{~g}$ due to the competition of potassium for the available sites. This is further evidence of the importance of the presence of competing cations in the system and indicates that a thorough knowledge of solution speciation is essential both for estimation and interpretation of adsorption data.

\section{Conclusions}

The cesium sorption experiments carried out on Grimsel mylonite, in the concentration range of $3.2 \cdot 10^{-8}-5.0 \cdot 10^{-4} \mathrm{M}$, suggested a reversible and concentration dependent (non-linear) mechanism. At least two different types of sorption sites appeared to be involved, depending on the cesium concentration. The high potassium concentration in the equilibrated water (compared to natural Grimsel groundwater), used for the laboratory experiments, made it necessary to check the competing effect of potassium on cesium sorption, since the potassium concentration in the groundwater, which is going to be used at the field site, might be much lower.

The decrease in the sorption coefficients of cesium with an increase in the potassium concentration in the solutions, is an indication of competition between cesium and potassium for sorption sites. The sorption of cesium at the lowest cesium concentration is considered to occur mainly at the crystal edge sites of micas. Using the sorption coefficients of cesium in two solutions with different potassium concentrations and the potassium concentration in the natural Grimsel groundwater, and assuming that at very low cesium concentrations (only using cesium tracer) sorption occurs predominantly at the crystal edges, and also assuming that the rock at the field behaves in the same way as the crushed rock used in the laboratory, the in-situ sorption coefficient for cesium can be calculated.

The fitting of data (not including the lowest Cs concentration, which is very close to the natural $\mathrm{Cs}$ level in groundwater) to Freundlich's equation gave a non-linear isotherm with a gradient of 0.60 . The Freundlich parameters were used in calculation of site distribution function mathematically for a binary exchange between cesium and potassium. This showed that (1) the exchange is not restricted to one specific class of sites, and (2) although most of the sites have a higher affinity for potassium than cesium, there is a small number of sites which have a higher affinity for cesium. 


\section{S. AKSOYOḠLU: CESIUM SORPTION ON MYLONITE}

The mean energy of sorption was obtained as about $12 \mathrm{~kJ} / \mathrm{mol}$, which is in the energy range of ion-exchange reactions, from the fitting of data to Dubinin-Radushkevich isotherm. The same isotherm yielded a maximum sorption capacity of about $95 \%$ of the total cation exchange capacity of mylonite, suggesting also that cesium sorbs predominantly by ion-exchange.

I would like to thank R. CORNELL and I. MCKINLEY for reading the manuscript and for their valuable comments. My thanks extend to B. BAEYENS and M. BRADBURY for the fruitful discussions and to M. MANTOVANI for her assistance in the experiments. Partial financial support by NAGRA is gratefully acknowledged.

\section{References}

1. I. G. McKINLEY, W. R. ALEXANDER, C. BAJO, U. FRICK, J. HADERMANN, F. A. HERZOG, E. HOEHN, Scientific Basis for Nuclear Waste Management, Vol. XI, 1988, p. 179.

2. Nagra Technical Report NTB 88-23 and PSI Report 28, M. BRADBURY (Ed.), 1989.

3. S. AKSOYOGLU, unpublished results.

4. J. MEYER, M. MAZUREK, W. R. ALEXANDER, In Nagra Technical Report NTB 88-23 and PSI Report 28, M. BRADBURY (Ed.), 1989.

5. B. L. SAWHNEY, Soil Sci. Soc. Proc., 28 (1964) 183.

6. A. A. TITLYANOVA, Soviet Soil Sci. (Engl trans), 12 (1964) 1313.

7. T. KAWABATA, J. Radiat. Res., 8 (1967) 20.

8. I. G. McKINLEY, J. M. WEST, Radioact. Waste Manag. Nucl. Fuel Cycle, 4 (1984) 379.

9. T. OHE, Nucl. Technol., 67 (1984) 92.

10. A. GRUETTER, H. R. von GUNTEN, E. ROESSLER, Clays Clay Minerals, 34 (1986) 677.

11. T. ERIKSEN, B. LOCKLUND, SKB Technical Report, 1987, SKB 87-22.

12. A. CREMERS, A. ELSEN, P. DEPRETER, A. MAES, Nature, 335 (1988) 247.

13. K. H. LIESER, T. STEINKOPFF, Radiochim. Acta, 46 (1989) 39.

14. J. F. RELYEA, L. L. AMES, R. J. SERNE, R. W. FULTON, C. D. WASHBURNE, Batch Kddeterminations with common minerals and representative groundwaters PNL, Richland, 1977.

15. R. CHHABRA, J. PLEYSIER, A. CREMERS, Proc. Int. Clay Conf., S. W. BAILEY (Ed.), Appl. Publs. Lim. 439, 1975.

16. M. POLEMIO, D. RHOADES, Soil Sci. Am. J., 41 (1977) 524.

17. G. H. BOLT, M. E. SUMNER, A. KAMPHORST, Soil Sci. Soc. Am. Proc., 27 (1963) 294.

18. W. RIEMAN III, H. F. WALTON, Ion Exchange in Analytical Chemistry, Intemational Series of Monographs in Analytical Chemistry, Vol. 38, Pergamon Press, Oxford, 1970.

19. H. NISHITA, P. TAYLOR, G. V. ALEXANDER, K. H. LARSON, Soil Sci., (1962) 94.

20. J. E. FERGUSSON, Inorganic Chemistry and the Earth, Pergamon Press, Oxford, 1982.

21. H. FREUNDLICH, Colloid and Capillary Chemistry, Methuen, London, 1926.

22. J. M. WEST, D. G. HAIGH, P. J. HOOKER, E. J. ROWE, Rept. Inst. Geol. Sci., FLPU 87-4, 1987.

23. I. G. McKINLEY, J. M. WEST, Rept. ENPU 81-6, 1981, Harwell.

24. K. SKAGIUS, G. SVEDBERG, I. NERETNIEKS, Nucl. Technol., 59 (1982) 302.

25. G. S. BARNEY, ACS Symp. Ser., 246 (1984) 3.

26. B. R. ERDAL (Ed.), Los Alamos Scientific Laboratory Report, LA-8339-PR, 1980.

27. R. J. SERNE, ONWI Technical Report, ONWI 9 (2), 1980. 
28. G. S. BARNEY, P. D. ANDERSON, PNL Report, PNL-SA-7352, 1978.

29. G. SPOSITO, Soil Sci. Soc. Am. J., 44 (1980) 652.

30. Z. SOKOLOWSKA, J. SZCZYPA, Geoderma, 24 (1980) 349.

31. G. SPOSITO, The Thermodynamics of Soil Solutions, Clarend on Press, Oxford, 1981.

32. M. M. DUbININ, L. V. RADUShKEVICH, Proc. Acad. Sci. Phys. Chem. Sec. USSR, 55 (1947) 331.

33. L. L. AMES, J. E. McGARRAH, B. A. WALKER, P. F. SALTER, Chem. Geol., 35 (1982) 205.

34. G. F. CEROFOLINI, Surface Sci., 24 (1971) 391.

35. J. P. HOBSON, J. Phys. Chem., 81 (1969) 2720.

36. F. HELFER RICH, Ion-Exchange, McGraw-Hill, New York, 1962.

37. P. F. SALTER, L. L. AMES, J. E. McGARRAH, Rockwell Hanford Operations Report, RHOBWI-LD-48, 1981. 